\title{
Relative Income and Marital Happiness Among Urban Chinese Women: The Moderating Role of Personal Commitment
}

\author{
Huiping Zhang $\cdot$ Sandra Kit Man Tsang
}

Published online: 2 November 2012

(C) The Author(s) 2012. This article is published with open access at Springerlink.com

\begin{abstract}
Compared with the rich knowledge in the West, studies of the impact of wives' relative income on marital quality during the fast socioeconomic change period in urban China have surprisingly fallen far behind. This study attempted to examine the impact of relative income on marital happiness among urban Chinese women. Using an urban Beijing sample of 763 married women, this study found that a woman married to a husband with lower income tended to be less happy with her marriage, but this effect will be countered if there is more love in the sense of a genuine concern about the well-being of the partner and a willing to make sacrifice for him. The results were interpreted from theoretical verification and possible mechanisms linking personal commitment and marital happiness.
\end{abstract}

Keywords Wives' relative income - Marital happiness - Personal commitment · Urban China

\section{Introduction}

Over the past decades, the impact of women's income on marital outcomes has been studied intensively in the west, and the mainstream line of study supported the economic independence hypothesis (Parsons 1949), that is, wives' relative income will lead to their marital dissatisfaction (Furdyna et al. 2008) and it is positively associated with the risk of divorce (Heckert et al. 1998; Rogers and Deboer 2001; Kalmijn et al. 2007). However, another line of study suggested that wives' income would add capital and assets to the marriage and enhance the quality of life for the family. This addition would presumably

\footnotetext{
H. Zhang $(\bowtie)$

Department of Social Work, The School of Sociology and Population Studies, Renmin University of China, No.59, Zhongguancun Street, Haidian District, Beijing 100872, People's Republic of China e-mail: zhp0205@gmail.com

\section{S. K. M. Tsang}

Department of Social Work, The University of Hong Kong, Pokfulam Road, Hong Kong,

People's Republic of China

e-mail: sandratang@hku.hk
} 
render the marriage more attractive to the couple and thus lower the risk of marital dissolution (Oppenheimer 1997; Sayer and Bianchi 2000). So, studies testing for the presence of an independence effect or an income effect have been generally inconclusive.

Mixed empirical results suggest that the models of the income effect or of the independence effect may not be comprehensive enough, it is necessary to focus on new variables that might moderate the relation between wives' relative income and the marriage (Lobl 2006; Sayer and Bianchi 2000). If the evidence for the effect of a given predictor is weak, it may be because it influences only some people but not others and thus it is very important to look for the moderators to move beyond the basic relationships between predictor and outcome (Frazier et al. 2004). The purpose of the present study is to examine the impact of urban Chinese wives' relative income on their marital happiness, and also examine the potential moderating role of personal commitment in this association.

\subsection{Wives' Relative Income and Marital Happiness}

An early attempt to talk about the link between wives' relative income and marital quality was the resource exchange theory (Thibaut and Kelly 1959; Homans 1961), which argued that in relationships people try to maximize self-interest through exchanging resources. Resources are anything of value, tangible or intangible, that couples bring to their relationship (Blood and Wolfe 1965). They include money, occupational or social status, education, love and affection, physical attractiveness, special knowledge or expertise, services (such as performing domestic labor), and so on. In the traditional marriage (e.g. male breadwinner-female homemaker family model), men contribute their incomes, as well as the status associated with their occupations, in exchange for women's domestic labor and child-care services.

This theory has been supported by many economists (Parsons 1949; Becker 1981), who contend that gender-based task specialization within marriage provides the most efficient system of exchange. The husband and wife within such families have complementary and specialized functions. Historically, men occupied a better position in the labor market, so couples relying on earning capacity will maximize their economic rewards; whilst a woman's contribution is maximized through their dedication to domestic work and children care. Based on this economic function and exchange approach, couples who do not follow this gender-based specialization model would be at a disadvantage in both the economic and domestic spheres, which may lead to lower marital happiness (Furdyna et al. 2008). The scenario is that an increase in wives' actual income and relative contributions may increase the sense of perceived unfairness over the households division of labor, challenge their husbands' power as head of the household, and cause them to experience greater marital dissatisfaction (Rogers 2004). So, we hypothesize that wives' relative income to family income is negatively associated with their marital happiness. That is, women with higher relative income to family income will be less happy in marriage than those with lower or equal relative income to family income.

\subsection{Personal Commitment and Marital Happiness}

Personal commitment is defined as a decision or a deliberate intention to continue a marital relationship, and as a psychological attachment to a specific partner and relationship (Adams and Jones 1997; Rusbult and Buunk 1993), which describes the extent to which marital happiness is associated with a strong sense of determination, and with the willingness to invest effort. Marital commitment can generate many pro-relationship 
behaviors, such as forgiveness (Finkel et al. 2002), accommodation (Rusbult and Verette 1991), and willing to sacrifice immediate well-being for the good of a partner (Rusbult and Buunk 1993). So, it is central to maintain a marital relationship (Arriaga and Agnew 2001).

After a thorough review of the marriage literature, Adams and Jones (1997) argued that marital commitment can be described in terms of three relatively broad dimensions; specifically, commitment reflects the degree to which spouses intend to maintain their marriage (a) because of their devotion to and satisfaction with their partner, (b) because of their belief in the sanctity of marriage as a sacred institution as well as their personal sense of obligation to honor their marriage vows, and (c) because of the desire to avoid financial or social penalties that might result from divorce or separation. However, the above conceptualization has received criticism recently.

Amato (2007) argued that it makes little sense to argue that people who are "trapped" in a relationship are considered as "committed" to it. So, it seems that only the concept of being committed due to intrinsic desire captures the meaning of commitment. In other words, commitment comes to sharp focus only when people are less than happily married and there are a few structural factors preventing them from leaving the relationship. Under these circumstances, some people will remain with their partners and others will not. Those who stay may believe or hope that the relationship will improve with time. Others may actively seek assistance with relationship problems. Therefore, in our study, only personal commitment is the focus of this study. Previous study has shown that personal commitment is strongly associated with marital happiness (Adams and Jones 1997), because personal commitment is an internally based choice to be in the relationship (Lydon 1999) and is primarily focused on relational rewards, including companionship and psychological attachment (Rusbult and Verette 1991). So, we hypothesize that women's personal commitment is positively associated with their marital happiness.

\subsection{Wives' Relative Income, Personal Commitment and Marital Happiness}

Resource theory assumes that marital exchange follows the market principle of self-interest maximization and the aim to receive an equitable distribution within family relationships (Homans 1961; Tribaut and Kelley 1959). In addition, equity-oriented exchange processes tend to be ingrained in a zero-sum game structure (Kranichfeld 1987). However, Rodman $(1967,1972)$ argued that resource theory must be placed within a cultural context.

Zuo (2008) proposed a relation-oriented exchange model in Chinese villages as opposed to an equity-oriented exchange model. She argued that relation-oriented exchange emphasizes spousal obligations to the family and to relational harmony. Husband and wife may not be seen merely as two anatomic sexes but as a bound, mutually dependent dyad whose personal interests may be closely identified with the collective well-being and whose marital exchange may take different trajectories as observed in industrial societies (Becker 1981; Parish and Whyte 1978; Zuo and Bian 2001; Zuo 2004). Although this model was developed in rural China, people with relational exchange orientation could also be prevalent in urban areas.

Wives who are personally committed to their marriage tend to orient their marital relationships toward the long run and they look beyond here and now, considering not only their economic contribution to the marriage, but also anticipating global contribution by their spouse in the future. In contrast, individuals are involved in a short-term relationship, and may monitor each other's contribution in order to act for their immediate self-interest. So, we hypothesize that personal commitment can buffer the negative impact of wives' relative income to family income on their marital happiness. 


\subsection{The Current Study}

The participation of married women in the labor market has been one of the most dramatic demographic changes to contemporary urban Chinese family (Edwige and Jin 2005). The employment of married women has led to greater economic contributions to their families, both in absolute terms and relative to their husbands' incomes. Compared with the rich knowledge in the West, studies of the impact of wives' relative income on marital happiness during the fast socioeconomic change period in urban China are surprisingly scarce. Some studies indicated that Asian couples put the priority on the interests of groups rather than individuals, that is, they tend to be more concerned about maximizing joint outcomes of the family rather than dividing the outcomes between the individual partners (Choi and Keith 1991; Park and Cho 1995). In summary, our hypotheses are elaborated as follow:

Hypothesis 1 Wives' relative income to family income is negatively associated with their marital happiness.

Hypothesis 2 Wives' personal commitment to marriage is positively associated with their marital happiness.

Hypothesis 3 Personal commitment moderates the association between wives' relative income and their marital happiness; i.e., there is a stronger negative relationship between wives' relative income and their marital happiness for lower commitment wives than for higher commitment wives.

\section{Method}

\subsection{Participants}

Based on the research questions and research purpose, 798 urban married women were recruited by a purposive sampling method through three classes in one primary school in Beijing in February 2010. 35 questionnaires were deleted due to incomplete information regarding wives' relative income, being second marriages, or that over half of these questionnaires were blank. The final urban sample was 763 wives with a mean age of 38.58 years $(S D=3.23)$ and a marital duration of 13.10 years $(S D=2.76) .55 .3 \%$ of them have obtained tertiary education, $32.9 \%$ have received secondary education or vocational training and $11.7 \%$ of them only received primary or below education. All of them were in their first marriage and $62.4 \%$ reported that they lived in a nuclear family. Nearly $90 \%$ of the participants were permanent residents of Beijing. The response rate was $79.8 \%$.

\subsection{Measures}

\subsubsection{Relative Income}

Wives' relative income refers to the wife's relative contribution to total family income. It is computed using the wife's annual income divided by the sum of both husband and wife's annual income. To be consistent with previous studies (Nock 2001; Rogers 2004; Teachman 2010), wives' relative income was considered as a nominal variable and three groups of wives were defined as: (1) lower-earning wives (0-39\%); (2) equal-earning 
wives (40-59 \%); (3) higher-earning wives (60-100\%). Relative income being higher given the family income means that the woman is married to a husband with lower income.

\subsubsection{Personal Commitment}

Personal commitment refers to being committed to the relationship or the partner in this study (Amato 2007). Because there is no validated Chinese personal commitment scale for this study, a self-developed scale with four items based on the interview of 25 Chinese married people was developed: (1) I am willing to melt away the unhappiness in marriage; (2) I am willing to balance what my spouse and I care about; (3) I often compromise in marriage; (4) I am willing to make great efforts to my marriage. Responses were rated on a 4-point Likert scale ( 1 = "totally disagree", $2=$ "disagree", $3=$ "agree", 4 = "totally agree"). The procedure to conceptualize personal commitment has been elaborated in one previous study (Zhang 2011). An index variable is computed with higher scores indicating more personal commitment to marriage. The reliability of personal commitment in this study is 0.87 .

\subsubsection{Marital Happiness}

Marital happiness was measured with a 12-item scale tapping the respondent's happiness with a range of aspects of the marriage, such as the sexual relationship, the division of household chores, and the amount of agreement between the couple. For example, participants were asked to indicate how happy they were with the amount of understanding they received from their spouse, the amount of love and affection they received from their spouse, the extent to which they and their spouse agreed about things, and their sexual relationship. Responses were rated on a 4-point Likert scale ( 1 = "very unhappy", 2 = "unhappy", 3 = "happy", $4=$ "very happy"). An index variable is computed with higher scores indicating a more happy marriage. The reliability of marital happiness in this study is 0.94 . Detailed information for this scale can be obtained from Johnson et al's study (1986).

\section{Results}

Table 1 presents the profiles of urban Chinese wives: lower-earning wives consisted of around $50 \%$, equal-earning wives consisted of $43 \%$, and higher-earning wives consisted of around $7 \%$. The $\chi^{2}$ and ANOVA test results suggested that these three groups of wives showed similar characteristics on both demographic and socioeconomic factors $(p>.05)$, which satisfied the requirements for the direct comparison among the three groups of wives.

Further analyses in Table 2 indicated that the significant main effect of relative income was found to be on marital happiness, $\mathrm{F}(2,746)=5.88, p<.01$. In general, higherearning wives reported lower marital happiness than lower- and equal-earning wives; however, there is no difference in marital happiness between lower and equal-earning wives $(p>.05)$. In other words, a woman married to a husband with lower income tended to be less happy with her marriage.

Based on the correlation analysis, the direct effect of personal commitment was found with respect to urban women's marital happiness $(\mathrm{r}=.65, p<.01)$. To examine the moderating effect of personal commitment, the predictor of wives' relative income (WRI) as a categorical variable with three levels was dummy coded as two variables: WRI2 (equal-earning) and WRI3 (higher-earning). Personal commitment and marital happiness 
Table 1 Characteristics of three groups of urban Chinese wives $(N=763)$

\begin{tabular}{llllll}
\hline & $\begin{array}{l}\text { Lower-earning } \\
(49.2 \%)\end{array}$ & $\begin{array}{l}\text { Equal-earning } \\
(43.9 \%)\end{array}$ & $\begin{array}{l}\text { Higher-earning } \\
(6.8 \%)\end{array}$ & $\begin{array}{l}\text { Test } \\
\text { statistics }\end{array}$ & $p$ value \\
\hline Age M (SD) & $38.30(2.93)$ & $38.79(3.55)$ & $39.30(3.23)$ & $\mathrm{F}=3.44$ & .05 \\
Years of marriage M (SD) & $12.92(2.46)$ & $13.32(3.09)$ & $12.96(2.56)$ & $\mathrm{F}=1.83$ & .16 \\
Education (\%) & & & & $\chi^{2}=9.40$ & .05 \\
$\quad$ Primary or below & 11.8 & 12.6 & 5.8 & & \\
Secondary & 37.4 & 27.9 & 32.7 & & \\
College or above & 50.8 & 59.5 & 61.5 & & \\
Family annual income $(\%)$ & & & & & \\
<44,000 RMB & 14.1 & 12.3 & 12.0 & & \\
44,001-80,000 RMB & 28.3 & 26.7 & 30.0 & & \\
80,001-115,000 RMB & 19.1 & 19.6 & 16.0 & & \\
115,001-150,000 RMB & 16.1 & 17.5 & 10.0 & & \\
150,001-185,000 RMB & 7.2 & 9.2 & 8.0 & & \\
$>185,000$ RMB & 15.2 & 14.7 & 24.0 & & \\
\hline
\end{tabular}

Table 2 Marital happiness by wives' relative income

\begin{tabular}{llllll}
\hline & $\begin{array}{l}\text { Lower-earning } \\
\text { M }(S D)\end{array}$ & $\begin{array}{l}\text { Equal-earning } \\
\text { M }(S D)\end{array}$ & $\begin{array}{l}\text { Higher-earning } \\
\text { M }(S D)\end{array}$ & F & Post hoc \\
\hline Marital happiness & $35.96(0.45)$ & $35.69(0.43)$ & $32.63(0.88)$ & $5.88^{* * *}$ & L, E > H
\end{tabular}

$L$ lower-earning wives, $E$ equal-earning wives, $H$ higher-earning wives

$* * p<.01$

were standardized before the regression. And two interaction terms were created, including WRI $\times$ PC and WRI3 $\times$ PC. As can be seen from Table 3, the moderating of personal commitment was found in the association between wives' relative income and marital happiness. When evaluated on the third step, the interaction between WRI and PC significantly contributed to the variance of urban wives' marital happiness, $\Delta F(1,760)=$ $8.76, p<.001, \Delta R^{2}=1 \%$. To better understand this result, separate correlations between WRI and MH were examined for wives who were one standard deviation above the mean of PC (high PC), and one standard deviation below the mean of PC (low PC). The differentiated correlations for the three groups are further shown in Fig. 1. For higherearning wives perceiving lower commitment to marriage, they tended to report lower marital happiness $\left(B_{2}=-2.59 \pm 1.71, t=-1.52, p>.05 ; B_{3}=-8.89 \pm 2.32, t=\right.$ $-3.84, p<.001)$; while for urban wives with higher commitment to marriage, WRI was unrelated to marital happiness $\left(B_{2}=.02 \pm .86, t=.03, p>.05 ; B_{3}=1.08 \pm 2.19\right.$, $t=.50, p>.05)$.

\section{Discussion}

We hypothesized that wives' relative income has a negative impact on their marital happiness. This hypothesis was supported in urban Chinese sample. However, the contribution of relative income to marital happiness was very small, ranging from 1 to $2 \%$. 
Table 3 The moderating effect of personal commitment on the relationship between wives' relative income and marital happiness

\begin{tabular}{|c|c|c|c|c|c|}
\hline Marital happiness & $B$ & $S E$ & $\beta$ & $\Delta F$ & $\Delta R^{2}$ \\
\hline Control variables & & & & $6.37 * * *$ & .03 \\
\hline Age & -.15 & .06 & $-.06^{*}$ & & \\
\hline \multicolumn{6}{|l|}{ Education } \\
\hline \multicolumn{6}{|l|}{ Primary school or below } \\
\hline Secondary or vocational training & -.74 & .69 & -.01 & & \\
\hline Tertiary education & -.95 & .68 & -.01 & & \\
\hline \multicolumn{6}{|l|}{ Family annual income } \\
\hline$\leq 80,000 \mathrm{RMB}$ & & & & & \\
\hline$>80,000 \mathrm{RMB}$ & 1.85 & .44 & $.08 * *$ & & \\
\hline Block one & & & & $8.71 * * *$ & .02 \\
\hline WRI2 & -.15 & .32 & -.01 & & \\
\hline WRI3 & -.56 & .67 & -.02 & & \\
\hline Block two & & & & $544.18 * * *$ & .38 \\
\hline $\mathrm{PC}$ & 3.17 & .22 & $.57 * * *$ & & \\
\hline Block three & & & & $8.76^{* * *}$ & .01 \\
\hline WRI $2 \times$ PC & .44 & .32 & .05 & & \\
\hline WRI $3 \times$ PC & 2.09 & .50 & $.14 * * *$ & & \\
\hline Total $R^{2}$ & & & & & .44 \\
\hline
\end{tabular}

WRI2, equal-earning wives, WRI3, higher-earning wives, $P C$, personal commitment. Beta coefficients are standardized

$* p<.05, * * p<.01 . * * * p<.001$

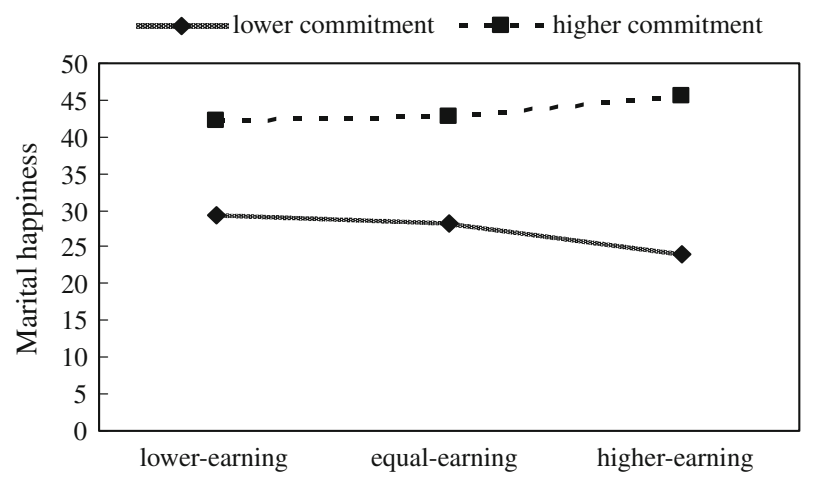

Fig. 1 The moderating effect of personal commitment on wives' relative income and marital happiness

Gong (2007) found that relative income is not associated with any dimension of marital quality for either husbands or wives, based on three American longitudinal datasets over the period of time from 1980 to 1996. Furthermore, Winslow-Bowe (2007) showed that wives' income advantage does not affect marital conflict as long as it is persistent in 4 or 5 years out of five.

Our interpretation for the small contribution of wives' relative income to marital happiness was that the changing family demography and gender norms regarding married 
women's employment may contribute to the low impact of wives' relative income on marital quality (Wilkie et al. 1998). For example, in the 1960s, American women's employment exerted a negative influence on marital quality, particularly for their husbands (Orden and Bradburn 1969). By the 1970s, studies found that there was no difference in marital quality for husbands and wives in dual-earner families and families in which the husband was the only wage earner (Glenn and Weaver 1978; Locksley 1980). However, from the 1980s to the present, evidence began to emerge showing that when wives have full-time employment there is a positive impact on marital quality (Simpson and England 1981; Schoen et al. 2006). Similarly, it has been a standardized life for urban Chinese married women to make economic contribution to the family, especially for prime aged families (Parish and Farrer 2000). Given the stability and recognition of wives' employment in the broader Chinese context over the past three decades, the impact of wives' relative income may not be so severe.

The second hypothesis that personal commitment was positively correlated with marital happiness was also supported in the urban Chinese samples. This finding indicates that wives who are willing to be committed to their marriage feel happy with their marriage, which is consistent with previous studies on personal commitment (Johnson et al. 1999), and relationship commitment (Arriaga and Agnew 2001; Le and Agnew 2003).

We have also found a moderating effect of personal commitment on the association between urban wives' relative income and marital happiness (only for higher-earning wives). This finding indicated the negative impact of wives' relative income on marital happiness will disappear when a higher-earning wife is committed to her partner and willing to sacrifice for him.

Firstly, Van Lange et al. (1997) argued that committed individuals are dependent on their partners, and need their relationships. Because committed higher-earning wives need their relationships, they are more likely to devalue the spousal income difference in order to sustain their relationships.

Secondly, strong commitment may be connected to a collectivistic, communal orientation, including tendencies to respond to a partner's income disadvantage in a rather unconditional manner. Communal orientation may decrease the possibility of higherearning wives pursuing self-interest (Clark and Mills 1979).

Thirdly, commitment involves long-term orientation (Arriaga and Agnew 2001). In short term involvement, higher-earning wives may achieve relatively good outcomes by behaving in accordance with maximizing their self-interest. In contrast, in long-term involvement, both spouses may be motivated to develop patterns of reciprocal cooperation.

There are three limitations that should be noted for further study. Firstly, the persistence of the wives' income advantage is unclear because of the cross-sectional data; therefore the impact of wives' relative income fluctuation on marital quality can not be obtained from this study. Secondly, the wives were approached through a school-base, so those wives without children or whose children drop out of school have been excluded. Children as an important investment in marital relationship may affect wives' personal commitment. A more representative sample of urban Chinese women should be investigated in future studies. Thirdly, the conceptualization of commitment should be broader, and moral and structural commitment should also be included as potential moderators.

This study confirms the importance of taking into account the moderating role of personal commitment in the association between wives' relative income and marital happiness. It informs our understanding of the negative impact of wives' relative income on marital happiness among urban Chinese women, whilst personal commitment is a good buffer for her marital happiness especially when the wife earns more than her husband. 
Acknowledgments This research has been supported by the National Social Sciences Fund of China (12CSH035). We would like to thank the useful and constructive suggestions from the anonymous reviewers.

Open Access This article is distributed under the terms of the Creative Commons Attribution License which permits any use, distribution, and reproduction in any medium, provided the original author(s) and the source are credited.

\section{References}

Adams, J. M., \& Jones, W. H. (1997). The conceptualization of marital commitment: An integrative analysis. Journal of Personality and Social Psychology, 72, 1177-1196.

Amato, P. R. (2007). Transformative processes in marriage: Some thoughts from a sociologist. Journal of Marriage and Family, 69(2), 305-309.

Arriaga, X., \& Agnew, C. (2001). Being committed: Affective, cognitive, and conative components of relationship commitment. Personality and Social Psychology Bulletin, 27(9), 1190.

Becker, G. S. (1981). A treatise on the family (Enl ed.). Cambridge: Harvard University Press.

Blood, R. O., \& Wolfe, D. M. (1965). Husbands \& wives: the dynamics of married living. New York: Free Press.

Choi, S., \& Keith, P. M. (1991). Are "worlds of pain" cross-cultural? : Korean working class marriages. Journal of Comparative Family Studies, 22(3), 293-312.

Clark, M., \& Mills, J. (1979). Interpersonal attraction in exchange and communal relationships. Journal of Personality and Social Psychology, 37(1), 12-24.

Edwige, K., \& Jin, X. R. (2005). Labour force participation of married women in China and Congo. Journal of Zhejiang University-Science A, 6(4), 350-354.

Finkel, E. J., Rusbult, C. E., Kumashiro, M., \& Hannon, P. A. (2002). Dealing with betrayal in close relationships: Does commitment promote forgiveness? Journal of Personality and Social Psychology, $82,956-974$.

Frazier, P., Tix, A., \& Barron, K. (2004). Testing moderator and mediator effects in counseling psychology research. Journal of Counseling Psychology, 51(1), 115-134.

Furdyna, H. E., Tucker, M. B., \& James, A. D. (2008). Relative spousal earnings and marital happiness among African American and white women. Journal of Marriage and Family, 70(2), 332-344.

Glenn, N., \& Weaver, C. (1978). A multivariate, multisurvey study of marital happiness. Journal of Marriage and the Family, 40, 269-282.

Gong, M. (2007). Does status inconsistency matter for marital quality? Journal of Family Issues, 28(12), 1582.

Heckert, D., Nowak, T., \& Snyder, K. (1998). The impact of husbands' and wives' relative earnings on marital disruption. Journal of Marriage and the Family, 690-703.

Homans, G. (1961). Social behavior: Its elementray forms. New York: Harcourt, Brace and World.

Johnson, D. R., White, L. K., Edeards, J. N., \& Booth, A. (1986). Dimensions of marital quality: Toward methodological and conceptual refinement. Journal of Family Issues, 7(1), 31-49.

Johnson, M., Caughlin, J., \& Huston, T. (1999). The tripartite nature of marital commitment: Personal, moral, and structural reasons to stay married. Journal of Marriage and the Family, 61(1), 160-177.

Kalmijn, M., Loeve, A., \& Manting, D. (2007). Income dynamics in couples and the dissolution of marriage and cohabitation. Demography, 44(1), 159-179.

Kranichfeld, M. L. (1987). Rethinking family power. Journal of Family Issues, 8, 187-216.

Le, B., \& Agnew, C. (2003). Commitment and its theorized determinants: A meta-analysis of the investment model. Personal Relationships, 10(1), 37-57.

Lobl, P. (2006). The effect of wives' relative income on marital closeness across national and international cultural contexts. Columbia University: Unpublished doctoral disseration.

Locksley, A. (1980). On the effects of wives' employment on marital adjustment and companionship. Journal of Marriage and Family, 42(2), 337-346.

Lydon, J. E. (1999). Commitment and adversity: A reciprocal relationship. In J. M. Adams \& W. H. Jones (Eds.), Handbook of interpersonal commitment and relationship stability (pp. 193-203). New York: Springer.

Nock, S. (2001). The marriages of equally dependent spouses. Journal of Family Issues, 22(6), 755-775.

Oppenheimer, V. (1997). Women's employment and the gain to marriage: The specialization and trading model. Annual Review of Sociology, 23(1), 431-453. 
Orden, S., \& Bradburn, N. (1969). Working wives and marital happiness. American Journal of Sociology, 74(4), 392-407.

Parish, W. L., \& Farrer, J. (2000). Gender and family. In W. F. Tang \& W. L. Parish (Eds.), Chinese urban life under reform: The changing social contract (pp. 232-272). Cambridge: Cambridge University Press.

Parish, W. L., \& Whyte, M. K. (1978). Village and family in contemporary China. Chicago: University of Chicago Press.

Park, I. H., \& Cho, L. (1995). Confucianism and the korean family. Journal of Comparative Family Studies, 26(1), 117-134.

Parsons, T. (1949). The social structure of the family. In R. Anshen (Ed.), The family: Its function and destiny (pp. 173-201). New York: Harper \& Brothers.

Rodman, H. (1967). Marital power in France, Greece, Yugoslavia, and the United States: A cross-national discussion. Journal of Marriage and the Family, 29(2), 320-324.

Rodman, H. (1972). Marital power and the theory of resources in cultural context. Journal of Comparative Family Studies, 3(1), 50-69.

Rogers, S. (2004). Dollars, dependency, and divorce: Four perspectives on the role of wives' income. Journal of Marriage and Family, 66(1), 59-74.

Rogers, S., \& DeBoer, D. (2001). Changes in wives' income: Effects on marital happiness, psychological well-being, and the risk of divorce. Journal of Marriage and the Family, 458-472.

Rusbult, C. E., \& Buunk, B. P. (1993). Commitment processes in close relationships: An interdependence analysis. Journal of Social and Personal Relationships, 10, 175-204.

Rusbult, C. E., \& Verette, J. (1991). An interdependence analysis of accommodation processes in close relationships. Representative Research in Social Psychology, 19, 3-33.

Sayer, L., \& Bianchi, S. (2000). Women's economic independence and the probability of divorce: A review and reexamination. Journal of Family Issues, 21(7), 906.

Schoen, R., Rogers, S., \& Amato, P. (2006). Wives'employment and spouses' marital happiness: Assessing the direction of influence using longitudinal couple data. Journal of Family Issues, 27(4), 506.

Simpson, I. H., \& England, P. (1981). Conjugal work roles and marital solidarity. Journal of Family Issues, 2(2), 180-204.

Teachman, J. (2010). Wives' economic resources and risk of divorce. Journal of Family Issues, 31, $1305-1323$.

Thibaut, J., \& Kelley, H. (1959). The social psychology of groups. New York: Wiley.

Van Lange, P., Rusbult, C., Drigotas, S., Arriaga, X., Witcher, B., \& Cox, C. (1997). Willingness to sacrifice in close relationships. Journal of Personality and Social Psychology, 72(6), 1373-1395.

Wilkie, J., Ferree, M., \& Ratcliff, K. (1998). Gender and fairness: Marital satisfaction in two-earner couples. Journal of Marriage and the Family, 577-594.

Winslow-Bowe, S. (2007). Relative income and mairtal conflict: The impact of fluctuating income advantages. Paper presented at Annual Meeting of American Sociological Association.

Zhang, H. (2011). Relative income and marital quality among urban Chinese women: A meaning-oriented resource exchange model. The University of Hong Kong: Unpublished doctoral dissertation.

Zuo, J. (2004). Feminization of agriculture, relational exchange, and perceived fairness in China: A case in Guangxi province. Rural Sociology, 69(4), 510-531.

Zuo, J. (2008). Marital construction of family power among male-out-migrant couples in a Chinese village: A relation-oriented exchange model. Journal of Family Issues, 29(5), 663.

Zuo, J., \& Bian, Y. (2001). Genderedresources, division of housework, and perceived fairness: A case in urban China. Journal of Marriage and the Family, 63, 1122-1133. 